\title{
FINANCING OPEN ACCESS: Introducing Friends of Cultural Anthropology
}

\author{
ANNE ALLISON \\ Duke University \\ (D) http:// orcid.org/0000-0001-8626-9550 \\ DOMINIC BOYER \\ Rice University \\ (D) http:/ / orcid.org/0000-0001-8944-406X \\ CHARLES PIOT \\ Duke University \\ (D) http: / / orcid.org/0000-0002-9166-9935
}

While Cultural Anthropology's move to open access has been positive in an abundance of ways, challenges remain. Foremost among these is finding alternative sources of funding in the current publishing environment, which is dominated by a small number of commercial presses that profit from leasing academic journals to university libraries. How, in Cultural Anthropology's case, do we cover the approximately $\$ 50,000$ that it costs to publish the journal each year? To address this pressing challenge, a group of Society for Cultural Anthropology (SCA) members has created a nonprofit to explore new avenues for fundraising. Called Friends of Cultural Anthropology (FoCA), this 501(c)(3) counts former editors, SCA officers, and other friends of the journal among its board of directors: George Marcus, Michael Fischer, Chris Kelty, Kim and Mike Fortun, Judy Farquhar, Bruce Grant, Danilyn Rutherford, Brad Weiss, Marisol de la Cadena, Bob Foster, and the three of us.

Moving forward, rather than relying solely on SCA dues and support from the universities that host the journal's editorial office, FoCA will explore a range 
of new revenue streams to support the journal's operations. Some of our initial ideas include:

- Using crowdfunding platforms like Kickstarter to sponsor particular projects. For example, if Cultural Anthropology were to undertake a substantial redevelopment of its website to improve the journal's publishing infrastructure or if it were to develop new features (like Sound and Vision, slated to launch later this year), crowdfunding could be an excellent way to pay for onetime projects.

- Applying for foundation grants to support larger, multiyear initiatives that might involve collaboration with other journals.

- Bringing back a recurring subscription to the journal's print edition, which is currently available for purchase on an individual issue basis, at a price point somewhat above the cost of production (perhaps $\$ 150$ a year). This would allow print subscribers to support Cultural Anthropology's open-access transition, while receiving a beautiful material object in return.

- Establishing an endowment. The experts with whom FoCA has consulted have unanimously advised that an endowment is, by far, the best way to stabilize Cultural Anthropology's financial situation in the long term. To raise these funds, our idea is to look beyond anthropologists and other scholars who are already supporting the journal through section memberships and donations. We know there are many individuals out there who value their undergraduate or graduate training in anthropology, and who would like to support innovative efforts to make research in our discipline more widely available. We also know that open access speaks to the core values of many who care about freedom of information, not least in places like Silicon Valley.

As FoCA develops, university libraries will also be key partners. Since libraries are the ones suffering the most from the current, commercially driven model of overpriced journal subscriptions, these institutions are often avid openaccess supporters. One new proposal for partnering with libraries - originating elsewhere, but running parallel to FoCA's efforts - is already in the works. Alberto Corsín Jiménez (the SCA's open-access advisor) and Giovanni da Col (editor-in-chief of $H A U)$, among others, are creating a multistakeholder publishing cooperative called Libraria, which would look to libraries for financial support of a dynamic portfolio of open-access journals. If this experiment succeeds and more 
journals continue to join the cooperative-ideally, including all of the journals published by the American Anthropological Association - it would secure a predictable, ongoing source of income for Cultural Anthropology and the other journals in the Libraria portfolio.

Since open access is, above all, a collaborative venture, we would welcome your help in building out Friends of Cultural Anthropology into a sustainable, vibrant organization. Please write to us directly or visit our website at www. friendsofca.org to share your comments and ideas. 